\title{
Failure of leadership in Nigeria
}

Ochulor, Chinenye Leo

\author{
Department of Philosophy, University of Calabar \\ Email: leoochulor@yahoo.com
}

\begin{abstract}
This paper argues in defence of the thesis that the leadership failure Nigerians experience is not the fault of their stars but the fault of leaders and the led alike. Nigerians should not abandon themselves to fate. The efficient leadership Nigerians are in dire need of, will remain a mirage except the leaders and the led, change their attitude to politics and politicking. The first step towards changing this attitude, the paper argues, is to carefully identify the causes of misrule in Nigeria. One's degree of success in articulating strategies for efficient leadership, is determined by one's degree of success in discovering the possible causes of misrule. As a nation, the accuracy of Nigerians in identifying the causes of misrule in Nigeria and their sincerity in redressing misrule in Nigeria, have serious implications for the efficient leadership that Nigerians are in dire need of, the Paper argues
\end{abstract}

Keywords: Leadership, failure, Nigeria

\section{INTRODUCTION}

In an opinion pool on power supply in Nigeria conducted by Vanguard newspaper, of Wednesday August 19, 2009 on page 14, all the respondents confirmed the popular view that Nigeria has never enjoyed uninterrupted power supply for even one day. The question was: How many hours of power supply in your area each day? "For the past four months, says one of the respondents, there has not been light in my area. Their excuse has been transformer (Power Holding Company of Nigeria, PHCN says that the absence of transformer in the respondent's area accounts for the light situation.) But the actual problem is that the head is sick". According to another respondent, "since last year, we have not had electricity supply. Then all of a sudden, about a week ago they had mercy on us and gave us power for seven hours. In Akesan, where I live, that was a major miracle. Their (PHCN's) excuse is that the step down transformer is the problem. But I link the power problem to failure of leadership. It is a government of the bourgeoisie". The above two respondents sum up the views of all the respondents namely, that power failure in Nigeria is a reflection of leadership failure in Nigeria. This paper seeks to discover the causes of leadership failure in Nigeria, with a view to articulating strategies for efficient leadership in Nigeria.

Has leadership in Nigeria failed? The fact that Nigeria, the seventh largest producer of crude oil in the world, imports fuel is a sign of leadership failure or misrule. The trouble with Nigeria, as Chinua Achebe (1983:1) rightly observed is simply a failure of leadership. This paper intends to do a careful study of the causes of misrule in Nigeria. This paper adopts library research and questionnaire methodology.

Causes of Misrule in Nigeria: I believe that for us Nigerians, the fault is not in their stars but in themselves. In Book IV of The Republic, Plato (1941) maintains that there is a breakdown of order in the state when the craftsmen or the soldiers try to usurp the ruling function which belongs, according to him, to the philosopher king(s), the higher of the two classes that make up the class of guardians. He believes that "the human race will not be free of evil, until either the stock of those who rightly and truly follow philosophy acquire political authority or the class of those who have power in the cities be led by some dispensation of providence to pursue philosophy". There must be, according to Plato, the willingness of the lower to be ruled by the higher. For there to be order in the society, the rulership of the state should be in the hands of those with the special talent and training that it requires. And, in Plato's opinion, the guardians must be free not only from the temptation to acquire property but also from the temptation to prefer the advantages of their respective families to those of the state. So unlike the craftsmen who may marry and own property, the guardians will have both property and wives in common. 
Aristotle (1932) in his book titled Politics (BK V) discusses revolution, its causes and prevention. In Chapter II of the book BK V, he treats the major causes of revolution. According to him, there are, generally speaking, three causes of revolution in a state. Firstly, those who desire equality enter on party strife if they think that they have too little although they are equals of those who have more; secondly, those who desire inequality or superiority do so if they suppose that although they are unequal, they have not got more but an equal amount or even less; he goes on to indicate that these desires may be felt justly, and they may also be felt unjustly, for when inferior people enter on strife that they may be equal and when equal they enter on strife in order that they may be greater. Thirdly, he identifies the objects of revolution as gain and honour and their opposites, for men carry on party faction in states in order to avoid dishonour and loss, either on their own behalf or on behalf of their friends. Other causes listed are insolence, fear, excessive predominance, contempt, disproportionate growth of power, election intrigue, carelessness, pettiness, and so on. Among these, the consequences of insolence and greed seem quite obvious; for when men in office show insolence and greed, people rise in revolt against one another and against the constitution that afforded the opportunity for such conduct. Greed sometimes preys on private property and sometimes on public funds. Then talking about revolutions in democracies, Aristotle in $\mathrm{Bk} V$ chapter IV of his Politics says that such are caused by the insolence of demagogues. These cause the owners of property to band together against the common people. Machiavelli in chapter three of The Prince talks of the evils that may arise in a state and holds that when the evils that arise have been foreseen, they can be quickly redressed but when, on account of their not having been foreseen, they are left to grow in a way that every one can see them, preventing them becomes an uphill task. He makes it clear that the ability to foresee evil is not common among men. The above three philosophers adequately summarize the fundamental causes of misrule in Nigeria. Let me isolate the causes, one from the other.

Lack of Intellectual Training and Discipline: One major cause of misrule in Nigeria is lack of intellectual training and discipline, on the part of leaders of our national government. This does not, however, mean that adequate intellectual training is necessarily a guarantee for good leadership, but it does help in this regard. The central theme of Plato's Republic is that society has to be governed by people-men and women-who have, through careful training attained the proper knowledge of human life and know the meaning of goodness in all its forms. Such knowledge makes a proper understanding of the purpose of government possible. Without it one can hardly govern well. Good government is the work of wisdom. It demands unusual virtue, intelligence, education, a great deal of experience and many other qualifications which cannot be expected to be possessed by any one person. So our leadership failures arise largely from the leaders themselves, from their intellectual incapacity, lack of discipline and political inexperience, not so much from the political institutions, not so much from the system. Once the operators of a given political system lack adequate knowledge and intellectual training, the system will not work. Much depends upon the operators of the system. For instance, Nigeria after independence practised the Parliamentary system of governmentWest minister model of democracy as bequeathed by her British colonizers. It did not work, but it is still working in Britain. The Military struck with the coup of $15^{\text {th }}$ January 1966. Then began the direct involvement of the military in Nigerian politics (19661979; 1983-1999). Between 1979 and 1983, the Shagari administration operated the presidential system (the White House model).

Intellectual incapacity, lack of discipline and political inexperience on the part of our leaders lead to venality of office. Montesquieu, according to Richter(1977) asks: Is it appropriate that public offices be sold (BK V, chapter XIX)? Venality of office was a practice of long standing in Montesquieu's day. Many government positions were sold like any other commodity. This makes the administration of a country highly inefficient. Talks about venality of office in Nigeria may sound paradoxical, but unpublished testimonies abound of people who paid thousands of naira to chief executives to get themselves appointed to high public offices and had to bribe members of Houses of Assembly to get such appointments approved. In the words of Iwe (1984:73)

Often political appointments are not based on evident competence and merit. The vested interests of the appointing authorities account far more than other factors. The common practice is to buy your way up to the position of authority. Having reached the coveted position, the incumbent begins to regard his office as an inherited divine right. There can be no question of resignation from office, 
even in the face of obvious gross misconduct or of evident general disaffection. Gross ineptitude and incompetence in office or highly questionable public probity of the incumbent are no obstacles to tenure of office here in Nigeria and other parts of West Africa.

Because they, as a result of their intellectual incapacity, lack a good understanding of the purpose of government, they -the chief executives - see their positions in government as opportunities to make money for themselves and favour their friends and relations. When offices are given to people either for money or by favour of he who bestows them, it would not be surprising if the beneficiaries lack the knowledge needed for the positions they occupy and so, like their benefactors, prove inefficient. Nigeria needs efficient leadership because inefficient leadership stifles good government and development. A leader with a clear knowledge of the purpose of government will take time to choose only those who can really help him reach the goal. But when a leader has no clear vision, then anything goes. That goes to say that lack of vision is compound by the absence of sense of direction. This sense of direction is important, but we Nigerians have all for a very long time become aware of our loss of a national sense of direction.

Approach the National Treasury with an Eye for Loot: Another cause of misrule in Nigeria is that our leaders approach the national treasury with an eye for loot. Such people have, among others, Thrasymachus as their spokesman. Thrasymachus according to Plato(1941) had occasion to address Socrates as follows:

Why, you imagine that a herdsman studies the interests of his flock and cattle, tending and fattening them up with some other end in view than his master's profit or his own; and so you don't see that in politics, the genuine ruler regards his subjects exactly like sheep and thinks of nothing else, night and day but the good he can get out of them for himself (BK 1.343).

Many Nigerian politicians have this spoils-view of politics and political activities. That to a large extent accounts for the abuses in government offices we daily experience in this country. Such people are surely thieves for they make secret illegal profits out of their offices. For most Nigerians, politics and political power are about the national cake. Politics of ideology has never been an issue among Nigerians.
What matters is politics of the national cake. And whoever has the national cake is he who has the support of the people. The negative impact of money in the political process has marginalized competent Nigerians with vision and leadership credentials. It has created a class of mediocre rulers who succumb to corruption and undemocratic practices. Those who think that being in government is nothing but a money making venture are dangerous enemies of this country. They are nothing but weak masters, who rather plunder their subjects than lead them. They promote mere personal or sectional interests thereby discriminating against some parts of the country. Such an attitude divides a country and can lead to all sorts of quarrel and some may decide to get by violence and robbery what they believe the government denies them. Posterity may not forgive those leaders whose leadership incapacity and greed has given rise to such situations as the Niger Delta conflict and kidnappings in Nigeria.

Talking about his two dads, Kiyosaki (2002:15) says: "Both men offered me advice but they did not advise the same things. Both men believed strongly in education but did not recommend the same course of study".

Who is advising our youths, especially Niger Delta youths? What advice do we give them? Do we give them guns and advise them to kidnap our political opponents? They later use the guns to rob and kidnap innocent citizens. Do we advise them to burst oil pipes and engage in oil bunkering, because of the financial benefits we derive from such unethical practices? Do we believe in the education of the youths? What do we recommend as courses of study for youths? Do we realize, as the former Governor of Rivers State of Nigeria, Chief Melford Okilo did in his convocation speech at the Rivers State College of Education, $10^{\text {th }}$ February, 1983 that: "In vain we build the nation and the city, unless we build the man"? Through kidnapping and bursting of oil pipes, many youths in the South-South and South-East acquire wealth for themselves and drive big jeeps. Who will help me teach the youths of this nation that: "To have real wealth in life, we Nigerians must cultivate the habit of acquiring wealth without violating the rights of others" (Ochulor 330)? A positive use of their youthful energies will guarantee a bright future for our youths. As Praise George (2005:51) rightly asked:

If for some unforeseen reason you suddenly had to stop doing what you are presently engaged in that earns you an income, will you be stranded or will you just think for a 
while, come up with a new strategy and move on to something new?.

The success of the current Federal Government amnesty offer to the militants of the Niger Delta depends largely on the willingness of the Niger Delta youths to stop kidnapping and bursting oil pipes as means of earning income for themselves and think of new and acceptable strategies for earning income for themselves. Who will help me teach the youths that by a careful analysis of themselves, their talents and capabilities, they should determine within themselves what they can offer to society through their products. And that they should plan ways and means of giving to society advantages, services, developments and ideas they can successfully deliver through ethically acceptable means. The Federal Government on its part should become genuinely interested in the youths and their welfare. The terribly high rate of youth unemployment is largely responsible for the kidnapping and youth restiveness we witness in Nigeria today. For now, government is yet to adequately strategize on ways of effectively tackling youth unemployment in Nigeria. Government should please do something urgently about youth unemployment. An idle mind is the devils workshop. As Uduigwomen (2009:33) rightly observed: "A person's moral standards emanate from different sources and influences" The sources according to Uduigwomen include: school, church, parents, the media, books, associations and even music plus such other sources as religion, peer group, family background and culture. All the above different sources affect person's moral standards. Let us help our youths to maintain acceptable moral standards by giving them acceptable means of livelihood.

Politics: A Spectator-sports: For many in Nigeria, politics remains a spectator-sports. This is another cause of misrule in this country. Nigeria belongs to all Nigerians and all must salvage it together. Nigerians should all be politically conscious, following intelligently the actions of government so that where it does well they commend it and when it begins to misgovern, they criticize and call it to order. This is what it means to control the business of government. Here freedom of expression is presupposed as a fundamental human right in the absence of which greed, tyranny and venality reign supreme. The Nigerian constitution expects Nigerians to control the business of government because according to it: "Sovereignty belongs to the people of Nigeria from whom government, through this constitution, derives all its powers and authority". Many Nigerians encourage bad leadership through defeatist silence. This silence in the face of bad leadership is the Nigerian people's way of contributing to bad leadership. There were twenty-nine years of military rule in Nigeria. That was unfortunate and it made nonsense of Nigeria's constitution. That the military can solve the political, social and economic problems of Nigeria is an illusion. There is need to do away with military rule and ensure an unbroken series of constitutional regimes. Nigerians need to eliminate the problem of succession and also make politics less glamorous and less commercially rewarding. Constitutional principles apply only to constitutional regimes and it is mostly in constitutional regimes that there can be genuine attempts at forestalling misrule. With the sovereignty of the Nigerian people regained through the abolition of military rule and with a government that has the people's mandate, one that through the constitution derives all its powers and authority from the Nigerian people, can then constitute the ultimate check over their governing personnel and aim at controlling the use of this power to ensure that it is used to their advantage. The heart of the matter here, is within the context of Senator Hillary Clinton's visit to Nigeria, August 2009, in her capacity as U.S. Secretary of State. It is about "election process" in Nigeria. It is about addressing the critical mass of the major causes of our electoral crisis cycle. It is about eliminating vote snatching, stuffing, hijacking and outright vote stealing. Nigeria's electoral system and processes have been hunted by "vote inflation, destruction, cancellation and vote snatching or hijacking", for a long time. This has eroded the confidence of voters and established an endemic voters' apathy amongst Nigerians. Indeed, this scenario constitutes the core challenge of Nigeria's electoral process-that is, the ability and capability to generate and deliver secured, authentic, transparent and generally acceptable electoral results. The solution, says Hillary Clinton, is automated election through e-voting (Vanguard Wednesday, August 19,2009:14).

Pressure On Public Servants : A further cause of misrule in Nigeria is the fact that Nigerians at times push their leaders into corrupt practices. People, villages, towns and communities whose sons and daughters are in government departments often make demands of them; such demands that can only be met by a corrupt use of one's office. If the demands are met, such incumbents become darlingsons of the soil. If they do not respond favourably, they are dubbed big fools. They will be treated with contempt and all kinds of calumny are rained upon 
them. With this distorted attitude, Nigerians in one way or the other compel their leaders to loot the public treasury. It is not surprising then that once a town has someone in government, it undergoes rapid transformation, depending on the person's office and its tenure. When he comes out of office, he will be given special reception and special titles "for having loved the town so much as to sacrifice the common good for it" Those towns which have not been blessed with someone in government, often do not dream of good roads, water, hospitals, electricity and so on. Leaders should be patriotic. They should realize that they are bound by the commitment of their offices to seek the common good. It is an injustice and a betrayal of trust for one to disappoint the nation for the sake of the parochial interest of a group or a small village or town. Thrasymachus in Plato's Republic thinks happiness and swell-being consist in getting more than one's fair share of what are commonly called the good things of life. Some there are in Nigeria who think that way and so they see nothing wrong in the abuse of office, because it is their turn to take from the 'national cake'. They, by so doing, perpetuate misrule.

Achebe's(1966) A Man of the People is a novel that shows the foolishness of some ideas about politics and the exercise of political power in Nigeria. The most unfortunate thing - and here lies the theme of the novel - about the corrupt but sociable chief Nanga, is that he is truly a man of the people. There are many Chief Nangas in Nigerian politics. The novel also reflects the social attitudes of the masses in Nigeria. They fail to give honest attention to even matters affecting their own destiny. They are the real offenders. They believe in the corrupt politicians. And if they are reminded that the politicians are corrupt, they excuse such corruption by saying that it is better to have their own man to exploit them than to have the white man to do so:

Let them eat was the people's opinion, after all when the white man used to do all the eating, did we commit suicide? Of course not... it may be your turn to eat tomorrow. Your son may bring home your share (161).

Nigerians, by and large, ask less of how and what is stolen but more of who stole and from where he comes. Accordingly the vital issues of public accountability and anti-corruption, unjust enrichment and abuse of office have become rather a wild goose chase of highly elusive targets. Nigerians have either actively or passively contributed to the misrule that has plunged this nation into a serious mess.
Montesquieu asserts that virtue is the principle of republics. By this he means that citizens must be attached to their state by principles that lead to genuine subordination of personal interest to national interest; that republics so far from being disorganized, must demand and receive iron discipline; and that all legislation must support the frugality and patriotism requisite of government personnel. He maintains that the love of the fatherland, which implies self-sacrificing-pursuit of the common good, is the principle of republics. Greed and apathy lead to misrule which in turn leads to lack of patriotism. Nigerian youths will be casting adrift their future, if they sit on the fence as the country drifts along. Nigerian youths, like the militant youths of modern Russia who volunteered to save their society at all cost, must pledge themselves to give themselves completely to the common cause of emancipating Nigeria.

Emphasis on Ethnic Origin: Emphasis on ethnic origin is yet another cause of misrule in Nigeria. It was Ojukwu (1989) who observed that "tribalism is perhaps the one factor that has nullified all our efforts at evolving a national leadership capable of fulfilling our national aspiration". I agree with him, the role he played in the Nigerian civil war notwithstanding. He believes that the civil war was fought by the Igbos of South-East Nigeria as a last resort, in self defense, to stop themselves from extinction. First in this regard is the fact that the regional structure of the nation is not balanced. The northern region alone is bigger than the other three - the Eastern, the Western and the Mid-western regions combined. Though states have been created to replace the regions, yet the influence of the regional structure is still very much with us. Eme Awa, ex-chairman of the National Electoral Commission (NEC) has noted that "Northern claim of numerical superiority over the south, with the resulting concentration of political power in the hands of Northerners, constitutes the greatest threat to the unity of the federation". That such a situation leads to misrule is quite obvious. This politics of ethnicity permitted and encouraged excessive regionalism and tribalism, nepotism and mediocrity in our national leadership. Hence, the then Head of State, General Obasanjo in 1979 opined thus:

One major cause of failure of civilian administration in this country was that our leaders concentrated on the part and ignored the whole; hence regionalism, tribalism, sectionalism and ethnicity became the order of the day (1979 New Year Message). 
With this observation made before the birth of the second Republic and similar ones made by other well meaning Nigerians ever since, one would have expected a change of attitude. But what has been the case? We are still concentrating on the part and ignoring the whole. The Yoruba socio-cultural organization, Afenifere, recently decried the inability of Yoruba governors to forge a common front on crucial matters affecting the interest of the Yoruba race. The group called on the South-West Governors to remain focused on "a common regional agenda". It noted that more than any other consideration, the single-minded resolve by the South-South governors to withdraw their commitment to the Federal Government amnesty offer to militants of Niger Delta, if government went ahead with a purported plan to relocate the proposed University of Petroleum Technology from Effurum, Delta State to Kaduna made the Federal Government to change its mind. Similarly, the group opined, the Northern governors called an emergency meeting and spoke with one voice on the "Boko Haram" crisis, with a view to forge a common policy on aliens coming to the North (Vanguard 11). Nigeria is a republic and a big one at that. Montesquieu, according to Richter (1977) argues that:

In a large republic the common good is sacrificed to any number of other considerations; it is subject to exceptions. It comes to depend on accidents. In a small republic, the public good is more keenly felt, better known, closer to every citizen, abuses are spread less widely, and consequently are less tolerated (BK VIII chapter XVI).

He goes on to say that,

In a large republic, there are large fortunes, and therefore but little moderation in the minds of men. Its resources are considerable... interests become increasingly individual. In it, a man may first come to feel that he can be happy, great, glorious, without his native land, then that he can only be great standing by himself upon the ruins of his native land (BK VIII chapter XVI).

Nigerians need to watch out ethnic tendency. As things stand in Nigeria, it is easy to lose sight of the common good and general welfare of the entire Nigerian populace and concentrate on promoting only the welfare of a group or a section. Nigerians sacrificed much between 1967 and 1970 to keep Nigeria together. Nigeria should be governed as one. Apart from Obasanjo who ruled Nigeria both as
Military Head of State and Civilian President and Ironsi who ruled Nigeria for six months as Military Head of State, no other Southerner has ever ruled Nigeria. The North, on the other hand, has produced one Prime-Minister, one Military President, one Civilian President and five Heads of State. A look at the roads in the Northern and Southern parts of Nigeria will make one wonder if both parts belong to the same nation. The roads in the North are so good while the roads in the South are so bad. Parochialism and ethnic affiliation account for the alarming difference in the development of both parts of Nigeria. According to Vanguard newspaper of Wednesday August 19,2009:11) 9:1a prominent traditional ruler in Ondo State (in Southern Nigeria) Oba Aderemi Atewogboye, the Alaani of Idoani has cried out over the pitiable state of some major roads in Ondo state and has appealed to the Federal Government to repair the federal roads linking Ondo State to neighbouring states. The government should not identify with any one group in any special way. Such identification, if permitted, can only promote misrule.

Weak Emphasis on The Rule of Law: This paper maintains that all should be bound by the country's laws. I advocate the supremacy of the law of the land over all. The idea of one law for the ruler and another for the ruled is an injustice. I uphold the principle of the Rule of Law which asserts the absolute supremacy of the law of the land and the equality of all before the law. President Yar'Adua's emphasis on the rule of law is highly commendable. Any political theory that does not uphold the rule of law will surely promote misrule in Nigeria. One such theory is Machiavelli's political theory.

Machiavelli's political advice shocked even his contemporaries. Some of them are advice for men who only want to seize and hold on to power. According to Machiavelli (1958:83), "it is necessary for a prince wishing to hold his own to know how to do wrong, and make use of it according to necessity" Montesquieu, though he admired Machiavelli, blamed him for advising rulers to use despotic means in dealing with their subjects. According to Richter(1977:326), Montesquieu certainly had The Prince in mind when he said,

But it was mad for Machiavelli to have recommended to princes as a way to maintain their pre-eminence, these principles necessary only to despotic government... This is unworthy of a mind as great as his.

Machiavelli encourages the quest for security at all cost and has no regard for the rule of law. Fear of insecurity 
and quest for security at all cost make Nigerian leaders often lean on some metropolitan political powers for protection. This violation of the rule of law is one of the causes of misrule in Nigeria. The issue of personal security on the part of the governing elite, to a very large extent, fosters misrule in Nigeria. The most efficacious way of securing one's office while in government is by the leader enjoying the popular goodwill of the people. This he can achieve by promoting the common welfare of all. The argument of security often put forth by defenders of what Achebe (1983) refers to as "official thuggery surrounding executive appearance in Nigeria" has never been persuasive. Cases of political assassinations are more rife in under-developed countries which indulge in the blandishment and celebration of power than in developed countries where the rule of law is supreme. A ruler who promotes the common welfare of all and as a result enjoys the popular goodwill of the people, will always have the support of his people. In such a case if coup plotters or conspirators threaten the personal security or government of such a leader, the people will most likely oppose such attempt, which it is most likely to regard as an evil design. Indeed the people should oppose it, determined to die rather than submit to such an evil design. Where such conspirators succeed in killing such a leader. The people should rise as one people and put them down as the Romans in Shakespeare's Julius Caesar did after Mark Anthony's speech. It is true that the historical Julius Caesar was a dictator who usurped absolute imperial powers in contravention of the republican constitution of Rome, but the treatment the people gave the conspirators in the play gives an idea of the type of resistance I have in mind. This will most likely rescue the leader's government as was the case when former Nigeria's Head of state Murtala Muhammed was assassinated. If unfortunately a leader is killed by conspirators but the people succeed in rescuing his government, then part of that leader lives on. Finally leaders should be careful and discriminating while dealing with people, particularly those who flatter them often or always. Flatterers can be as dangerous as conspirators. With regard to the causes of misrule in Nigeria, I am of the view that the fault lies not so much in the system but in the caliber of leaders and the led.

\section{CONCLUSION}

Investigations in this paper show that the Nigerian leaders take the greater blame for leadership failure in Nigeria but the led also have a share of the blame because of their various ways of encouraging bad leadership for the sake of selfish gain. If the facets of misrule in Nigeria are to be encountered, Nigerian leaders must shun selfish tendencies and promote the common good of the Nigerian people through peopleoriented leadership.

In conclusion, therefore, I see misrule as a spiritual, civic and national challenge. As mature and responsible citizens of modern Nigeria, it is the people's duty to take this challenge individually and collectively. Nigerians must fight misrule in all its forms and ramifications and in all its pomp and pageantry. This is a civic and national task and challenge. The people of Nigeria must insist on good leadership by resisting bad leadership at all costs, including the sacrifice of individual or collective lives. No country gets good leadership on a platter of gold. All hands must be on deck to ensure that leadership in Nigeria becomes and remains good and people-oriented.

\section{REFERENCES}

Achebe, Chinua(1966), A Man of the People. London: Heinemann.

Achebe, Chinua(1983), The Trouble with Nigeria. Enugu: Fourth Dimension publishing Co. Ltd.

Aristotle. Politics. With an English translation by H. Rackham, M.A. London: William Heinemann, 1932.

Constitution of the Federal Republic of Nigeria 1999.

Ikoku,S.G (1984), Nigeria's Fourth Coup: Options for Modern Statehood. Enugu: Fourth Dimension Publishers.

Iwe, N.S.S (1984), "The Reality of the Nigerian Social SceneSelfishness" AMAN: Journal of Society, Culture and Environment, 3.2. (1984):71-80.

Kiyosaki, Robert T(2002), Rich Dad, Poor Dad. Britain: Warner Book.

Machiavelli N(1958), The Prince. London: J.M. Dent and Sons Ltd.

Obasanjo, O(1979), New Year Message. Daily Times Publication, Jan1, 1979.

Ochulor, C.L(2008), Philosophy: A Fundamental and Basic Science. Calabar: Focus Prints and Publishers.

Ojiako, J.O(1981), Nigeria: Yesterday, Today and...? Onitsha: Africana Educational publishers.

Ojukwu C.O (1989), Because I am Involved. Ibadan: Spectrum Book Ltd.

Plato(1941), The Republic. London: Oxford University Press.

Praise George(2005), Mastering Money. Lagos: Success World Ltd.

Richter M(1977), The Political Theory of Montesquieu. London,Cambridge University Press.

Uduigwomen, A.F(2009), A Companion of Christian Philosophy And Apologetics. Calabar: Ultimate Index book Publishers.

Vanguard Newspaper(2009), Vol. 25: No 60914 Wednesday, August 19 